\title{
Literature Review of Financing Structure of Multinational Corporations
}

\author{
Bo Deng \\ School of Nanjing University of Science and Technology, Nanjing 210000, China \\ 1183042761@qq.com
}

Keywords: multinational corporations; debt financing; financing structure

\begin{abstract}
This paper presents a theoretical review of the debt financing structure of multinational corporations, summarizes and analyzes the theoretical basis for the research on debt financing structure in domestic and foreign companies from different perspectives. It is hoped to provide a reference for the research on the financing structure of multinational corporations.
\end{abstract}

\section{Introduction}

Debt financing refers to the process of financing from banks or non-bank financial institutions. It is one of the most commonly used financing methods of enterprises, and it is formed on the basis of the potential conflicts between interest and information asymmetry between lenders and borrowers. The debt financing structure is an important topic and direction of debt financing research.

With the development of economic globalization, multinational corporations, as a form of the most advanced corporate organization, have a tremendous and far-reaching impact on the world economy today. More and more companies have adjusted past domestic development strategies to global development strategies. Multinational corporations have become the norm for business operations. Among these, the number of Chinese multinational corporations is also increasing. In modern multinational corporate financing activities, the financing structure is often regarded as the focus of attention. Compared with companies operating solely in their own country, under the combined influence of external macro-environmental influence factors and the micro-influence factors of multinational corporations themselves, the financing structure of multinational corporations will be affected to a certain degree, presenting a different financing structure from domestic companies.

At present, the development of China's multinational corporations is very rapid, and it plays an important role in the process of our country's economic globalization. However, with the rapid development of multinational corporations, the problems caused by their financing structures have also been continuously presented. In the economic environment of our country, the financing structure of China's multinational corporations has occurred a different trend from the western developed countries. According to the relevant research on the theory of new financing order, the financing structure of multinationals should be first internal financing, debt financing and final equity financing. However, the financing order of China's multinational corporations is first equity financing, debt financing, and finally internal financing. Opposite to the optimal financing structure. 
Whether the financing structure of a multinational corporation is reasonable or not is directly related to the level of its financing costs, which in turn directly affects the long-term development of multinational corporations. Therefore, it is of theoretical and practical significance to study the financing structure of multinational corporations in order to constantly improve the financing structure of China's multinational corporations and promote their long-term development.

\section{The Selection of Financing Structures of Multinational Corporations}

\subsection{The relationship between multinational operating model and debt level}

In the literature research on the financing structure of multinational corporations, more foreign documents provide information on the relationship between multinational operating models and debt levels. The level of debt as an integral part of the financing structure is a good entry point for studying the financing structure of multinational corporations.

Early studies explained the relationship between the company's multinational operations and the level of debt and found that the leverage ratio of multinational corporations is lower than that of non-multinational corporations (Burgman, 1996). The reasons are that, on the one hand, multinational corporations set up branches and subsidiaries in different countries. It is very difficult to supervise large multinational corporations (Chkir and Cosset, 2001); On the other hand, an internationalized and diversified business model will increase the debt agency costs of multinational corporations at the corporate level, that is, it is even more difficult for creditor holders to supervise the various operating activities of multinational corporations than to monitor domestic corporations. Therefore, a higher rate of return on claims will be required, which will increase the cost of debt financing of multinational corporations. In the above two points, multinational operations will lead to a relatively low level of debt financing in the corporate financing structure (Doukas and Pantzalis, 2003). Shleifer and Vishny(1992) and Stein(1997) also believe that the company's multinational operating model will lead to lower debt levels, but gives a different perspective to explain that they believe that companies with multinational operating models operate in different countries. And the company's business is relatively more diversified, which makes multinational corporations conditionally develop a wide range of internal capital markets. In the internal capital markets of multinational corporations, information asymmetry and other issues that often occur in external capital markets will not happen in internal capital markets, so that it can provide lower internal financing costs than external financing. Therefore, the proportion of debt financing of multinational corporations is lower than that of non-multinational corporations.

However, there also exists some literature that gives the opposite evidence for the relationship between multinational operating models and the level of debt. Refer to comparative evidence that Reeb et al.(2001) provides: multinational corporations tend to have lower costs of debt financing; Mansi and Reeb(2002) believe that the relationship between internationalization activities and corporate operating costs and debt levels is non-monotonic. In the low internationalization level of multinational corporations, there is a negative correlation between internationalization activities and the company's operating costs and debt levels. That is, multinational corporations will lower the cost and debt level of multinational corporations; however, when the internationalization level of multinational corporations is high, they find that the debt level of multinational corporations is also relatively high. That is, when multinational corporations have a high level of internationalization, multinational operations and debt levels are positively correlated. The proportion of debt financing in the financing structure of multinational corporations was higher than non-multinational corporations. Mittoo and Zhang (2008) found that Canadian multinational corporations have the opportunity to enter the international financial bond market due to their multinational operating model, so that these multinational corporations can use debts and other means to use higher levels 
of debt. Based on this, they come to a further conclusion: There is a complex interaction between the financing structure of multinational corporations and the level of financial development in the host country, namely the country where multinational corporations invest or merge and acquire.

The latest research on the relationship between multinational corporations' multinational operating model and financing structure is an empirical analysis of Halit Gonenc and Daniel J.de Haan(2014). The author analyzed the relationship between the level of internationalization and the level of debt financing in 31 developing countries from 1991 to 2006. This document reveals that the relationship between the company's multinational operations and financing methods is also affected at the national and corporate levels. At the national level, if the home country of a multinational corporation is in a higher financial level, the actual operation of multinational corporations will correspond to a higher debt financing level. At the corporate level, if the multinational corporation's internationalization level is higher and there is a higher proportion of foreign sales, the multinational corporation will have the opportunity to obtain a lot of debt financing in the actual operational process. It analyzed the relationship between multinational operating and debt financing from the perspective of the national level and the corporate level.

\subsection{International Comparison of Financing Structure}

There are many international comparison documents on financing structure of domestic and abroad companies. There are also many independent research objects of multinational corporations. Hong Qing(2004) proved that the corporate financing structure plays a decisive role in corporate governance structure. The article used British and American companies and Japanese and German companies as sample objects, summarized typical characteristics of the Anglo-American model and the Japanese-German model: Anglo-American companies tend to finance directly from the stock market, the company shares are more decentralized, and Japanese-German companies mainly finance through bank loans, relatively concentrate on equity. The authors further conducted empirical analysis of the sample and obtained the equity ratio of the two companies. U.S. companies held the highest proportion of individual shares, up to $50.2 \%$, and British companies also had 28.0\%, while the corresponding ratio between Japan and Germany was $22.4 \%$ and $17 \%$ which are lower than Anglo-American companies. The analysis of its causes reveals that the financing situation of Anglo-American and Japanese-German firms and China's multinational corporations is very different. It is not possible to copy the two models. It is necessary to further analyze the companies in China and adapt them according to China's specific national conditions. The analysis of the sample company's data is very detailed, but the analysis of the reasons behind it and the suggestions put forward are relatively superficial and not deep enough.

According to Western capital structure theory, the general mode of corporate preferential financing is internal financing, debt financing, and finally equity financing. However, the financing order of listed companies in China is contrary to the classics. Zhang Yingming et al.(2005) counted the historical data of domestic listed companies. Among the listed companies with positive undistributed profits between 1995 and 2000, the proportion of internal financing is only 15\% on average, and the proportion of internal financing of listed companies with negative undistributed profits is about $3.385 \%$ on average, it can be seen that China's listed companies strongly prefer external financing for corporate financing; further analysis of the external financing structure of domestic listed companies shows that equity financing is higher than debt financing; in addition, statistical data also show that the listed company's debt-to-equity ratio is low. These data fully show the "reverse" financing preferences of China's listed companies: foreign financing has a priority over internal financing. In the foreign financing that dominates the corporate financing structure, equity financing also takes precedence over debt financing. It contradicts the general principles of 
financing priorities proposed by Meyers et al. in the Western countries. As for the reasons for the strange phenomenon of the financing of domestic listed companies, the author thinks that China's positioning of the domestic capital market and the differentiation of the domestic market structure are the key reasons.

\subsection{Influencing factors of financing structure}

Chen Wengang(2005) made an empirical analysis of the factors affecting the company's financing structure. The sample data came from 84 commercial and trading companies listed on the Shanghai and Shenzhen stock exchanges. Empirical analysis found that the company's financing structure showed strong industry differences. It is understandable that the financing structure of a company differs depending on the industry in which it operates. Therefore, the analysis of the factors affecting the financing structure is more superficial. Li Zhiguo(2009) conducted a comprehensive analysis of the differences in the financing structure of seven developed country companies including China, the United States, and Japan, and found that listed companies in China are strongly inclined to equity financing. The author believes that the listed companies in China are still in the early stage of development and are affected by various internal and external economic factors. The financing structure inevitably has irrational places. Therefore, the optimization of financing structure and strategic management are the highlight of company's strategies management. Finally, the author proposes that China should combine the characteristics of the domestic capital market structure and learn from foreign advanced experience to develop a capital market with Chinese characteristics. However, the author did not give a definite analysis of how to draw lessons from foreign experience and what kind of experience foreign countries learn from. Wang Zongjun(2009) studied the relationship between the financing structure and investment of listed companies. The analysis of the article shows that the influence of company investment on the financing structure of the company is non-linear. Different investment levels have different effects on the financing structure of the company. Capital investment may increase the company's debt-to-equity ratio, and may also reduce the company's debt-to-equity ratio. The model confirms that the company's financing structure is a three-fold function of investment.

\section{The Effect of Agency Costs on Financing Structure of Multinational Corporations}

This article regards the company's financing structure as a balance achieved between the company's three kinds of agency costs. The three types of agency costs are: the agency cost between managers and shareholders, and between shareholders and creditors, and between large shareholders and small and medium shareholders.

\subsection{Agency costs between company management and shareholders}

In listed companies, there is a separation between ownership and management rights under normal circumstances. Management as managers of companies do not actually have ownership of the company, and there may exists situations in which interests are inconsistent between management and shareholders. That is, there exists agency costs.

Li Shuangfei et al. (2007) believe that debt financing can reduce the company's internal agency costs. The mechanism is that debt financing can increase the relative shareholding ratio of managers, so that the interests of the company's management and shareholders can be closer together to improve the efficiency of managers' work. The data of empirical analysis comes from all A-share listed companies in China from 1998 to 2005. The statistical results show that the net debt financing of listed companies accounts for approximately $2.27 \%$ of the total assets; the debt-to-asset ratio has 
a great influence in the relationship between corporate debt financing and company value. For listed companies with ratios between $30 \%$ and $60 \%$, debt financing has the most significant effect on increasing the market value of the company, and excessive or too low ratios do not have this effect. Jensen and Murphy (1990) pointed out that company managers' holding shares always have an incentive effect and it has nothing to do with the form of the stocks held, however, according to how the company's managerial holdings affect the company's financing structure has not yet formed a unified opinion. While the results of Mehran.H.(1995) indicate that there is a significant linear positive correlation between the proportion of corporate executives', especially the senior managers' holdings and the company's financing structure and debt-to-equity ratio. McConnell (1990) used cross-section sample data of Fortune 500 manufacturing companies to conduct an empirical study, and the results prove that there is a non-linear relationship between the financing structure of the company and managers' shareholdings. Yi Chuilin(2009) used the data of the listed companies in Shanghai and Shenzhen in 2008 to study the relationship between the company's managerial holdings and the financing structure of the company. The sample data included 771 companies, and the research results show that there is a significant cubic curve relationship between the ratio of managers' holdings and the company's value. Jin Tian et al.(2005) believe that the diversification of a company will have an impact on the company's financing structure.

\subsection{Agency costs between shareholders and creditors}

The second agency cost of listed companies is the agency cost between shareholders and creditors. Since the shareholders of a listed company have limited liability to the company, they are motivated to carry out high-risk investment. When the investment is successful, they can obtain excess returns. And if the investment fails, their losses have been locked, but the creditors need to bear the risk of investment failure. There exists some documents in this respect, for example, Zhang Lida et al.(2008) constructed an interaction model between the company's equity structure, debt structure, and capital structure, and validated the model based on 2005 data from Shanghai and Shenzhen stock exchange sample companies.

\subsection{Agency costs between major shareholders and small and medium shareholders}

The research on this issue mainly focuses on the impact of agency costs between large shareholders and small and medium shareholders on the value of the company and the structure of company's equity. There are many documents on the impact of agency costs on the value of the company, but documents on the impact of the structure of company's equity are very few. Wu Gang et al.(2008) found that in China, the listed company's agency costs between the controlling shareholders and the small and medium-sized shareholders are widespread. The author's self-defined share ratio exceeds $30 \%$ for the controlling shareholder, and further subdivides the major shareholder holding company (relative holding, absolute holding) and holding type (government holding, family holding and other holdings). The result shows that the type of equity has a great influence on the controlling ratio and the company's value: the two have a U-shaped curve with left high and right low under the government's controlling situation; for a privately-controlled company, the relationship between the two shows a horizontal S-curve relationship. The authors also found that under the control of the government, different types of holdings have little effect on the value of the company, but in the case of family holding, relative holding is more conducive to increasing the value of the company. Our research provides a new perspective, but the theoretical analysis of the article still needs to be strengthened. Zhang Yuyao(2008) believes that the lower the level of protection of minority shareholders' interests, the more significant the strengthening effect of controlling power of large shareholders. The influence 
of non-fair related party transactions made by major shareholders of listed companies in China on the value of the company has been empirically proved, and he also discovered that non-fair related party transactions will lead to further separation of control rights and cash flow rights, and the higher the degree of separation, the lower the value of the company. Zhang Tianyang et al.(2009) reached similar conclusions on the study of the influence of the separation of cash flow rights and control rights held by the ultimate controller of a listed company and the company value. The author verified the conclusions of the 196 listed companies whose ultimate controllers are natural persons, families, and private companies disclosed in the annual report of China listed before 2008. However, the article only analyzed the influence of the controlling rights of large shareholders on the value of the company, and did not further analyze the influence of controlling rights on the financing structure of the company. Zhang Zhaonan et al. (2009) believe that there are regional differences in the level of domestic investor protection, and this difference will have an impact on the agency costs between large shareholders and small and medium shareholders. The author constructed the corporate governance environment index in different regions based on the marketization process data of various regions in China compiled by Fan Gang and Wang Xiaolu. And the research was based on the 1996-2006 data of China's A-share listed companies, the author empirically studied the relationship between the corporate governance environment and cash holdings in different regions and company's value and found that when the other conditions are same, the better the corporate governance environment is, the higher the protection level for investors is, the more difficult it is for large shareholders to infringe upon the interests of minority shareholders; at the same time, the better the corporate governance environment is, the more cash that the company will have, and thus the company's value will be higher.

\section{Conclusion}

Throughout the above research literature on the multinational corporations or international comparison of financing structures, it is found that most of the literature have analyzed the international differences in the financing structure and the causes of deviations in the financing structure of listed companies in China. They only analyzed from a certain perspective and may not comprehensive enough. The depth and breadth of analysis needs to be improved. In addition, research on the relationship between financing structure and agency costs existing within the company has been conducted by a large number of detailed studies, including the agency costs between large shareholders and small and medium shareholders as an important factor affecting corporate financing decisions. However, there is still a lot of room for innovation in this area.

\section{References}

[1] Antoniou, A.,Guney, Y. and Paudyal, K. (2008), “The determinants of capital structure: capital market-oriented versus bank-oriented institutions”, Journal of Financial and Quantitative Analysis, Vol. 43 No.1, pp. 59-92.

[2] Frank, M.Z. and Goyal, V.K. (2009), “Capital structure decisions: which factors are reliably important?” Financial Management, Vol. 38 No. 1, pp. 1-37.

[3] Lemma, T.T. (2012), "Capital and debt maturity structures of a firm: evidence from selected African countries", unpublished PhD thesis, University of the Witwatersrand, Johannesburg.

[4] Halit Gonenc; DanielJ. De Haan (2014), “Firm Internationalization and Capital Structure in Developing Countries: The Role of Financial Development”. Emerging Markets Finance and Trade, Vol.50 No.2, pp. 169-189. 